\title{
Women in TVET: Contestation of Agency and Patriarchal Power for Liberation
}

\author{
Indra Mani Rai ${ }^{1} *$ (D), and Pashupati Joshi ${ }^{2}$ \\ ${ }^{1}$ Central Department of Education, Tribhuvan University, Kathmandu, Nepal \\ ${ }^{2}$ Training Institute for Technical Instruction, Bhaktapur, Nepal
}

\begin{abstract}
Against the effort made through Technical and Vocational Education and Training (TVET) in ensuring gender equality through providing women with the self/employment opportunities, there exists under-representation of them particularly in male-dominated training courses and jobs. In this context, the paper, based on a qualitative case study of three women who engaged in the courses and then occupations, portrays their struggles for coping with the gender stereotypes of devaluing women's capability in the context of patriarchal power domination. Visualising from the feminist power perspectives, we came to the insights that the women's agency (willingness, commitment, motivation, and knowledgeability) contests with the power held by males and patriarchal social structures. The negotiation of within self-power of women and external power of males and society support to unleash them for making a choice of career path.
\end{abstract}

Keywords: TVET, power, agency, gender stereotypes, patriarchy

\section{The Context}

In many developing countries, the importance of Technical and Vocational Education and Training (TVET) is perceived with three main roles. First, TVET provides skills and knowledge, thereby enhancing the opportunity of self/employment

* Corresponding Author.

(日) indrayamphuny@gmail.com
ISSN: 2091-0118 (Print) / 2091-2560 (Online)

(C) 2020 The Author(s).

Journal homepages: ${ }^{1}$ http://www.kusoed.edu.np/journal/index.php/je

${ }^{2}$ https://www.nepjol.info/index.php/JER/index

Published by Kathmandu University School of Education, Lalitpur, Nepal.

This open access article is distributed under a Creative Commons Attribution (CC BY-SA 4.0) license. 
for individuals. Second, it improves economic development by skill-based enterprise through the skilled human resource. Third, it is viewed as an instrument to overcome gender inequality. Further, it is believed that TVET contributes to reducing poverty, promoting equity and fairness (Demissie, 2017). With its strong emphasis on reducing gender inequality, women participation has become a key feature of discussion in education policy and practice. However, the women participation in TVET programmes is less in comparison to men which has made it difficult to maintain fundamental social values such as equity, justice, and gender equality (Duflo, 2012). A gender stereotype is one such key force that has been hindering to promote these values, thereby providing access to the skill development of women, particularly in the TVET sector.

In the Nepali context, women, in general, are considered physically weaker and less capable than men (Pandey, 2014). They often face multiple forms of gender-based violence such as physical, sexual, mental and emotional abuses. Many parents and community members also have the attitude that educating girls is a waste of time and money because they will eventfully be married off and their education only benefit their husbands and the families they marry into (Hart, 2008). There is still a division of labour within the household that women are assigned the household chores by which they face difficulties in accessing education and economic opportunities. There are social stereotypes that Nepali women, in many cases, engage in specific traditional occupations such as tailoring, beautician, handicraft, pashmina knitting, hand embroidery, garment fabricator, Dhaka (local clothes) weaving, housekeeping and so on. However, males engage stereotypically non-women occupations such as plumbing, electrical, welding, aluminium fabricator, motorcycle mechanic, bar bending, furniture making, masonry, bricklaying, mobile repairing and maintenance, light driving, mechanical lathe operator, automobile, and so on (Helvetas Swiss Inter-cooperation Nepal, 2013). Women are supposed to be unable to engage in these male-dominated occupations. This is a structural division of labour in Nepali society. This has provided very limited opportunities for Nepali women to work outside the household (Choe, 2005).

The prevailing socio-cultural norms and values created by patriarchal authoritarian family structure have made males superior to females dominating their personal, social and domestic life (Gyawali, 2011). That is why the Nepalese women are socially and economically dependent on the authority of men. They have less freedom to choose 


\section{8 | I. M. Rai \& P. Joshi}

their valued professions, particularly in rural contexts (Budhathoki et al., 2012). Thus, women are in disadvantaged positions in education and economic status. Realising the facts, the Council for Technical and Vocational Education and Training (CTEVT, 2005) under the Ministry of Education, Science and Technology, Nepal, has put efforts on to develop the TVET services (short term and long term training courses) for preparing women for employment and uplifting their economic status. However, the reality appears very less as desired in terms of promoting equity and inclusion of women in male-dominated TVET programmes such as in the courses of plumbing, metalwork, and carpentry and so on (Bhattarai, 2017).

In this context, this paper explores the experiences of women who were engaging in male-dominated (so-called males' works) TVET related training and occupations, particularly on in non-traditional trade areas. The paper highlights the structural domination, lack of freedom and choices, and stereotypes the women are facing in regards to choosing male-dominated training and jobs. The paper argues that the women who hold agency (motivation, commitment, knowledgeability, the capacity of selecting valued work) as inherent power are resisting to the power held by men in patriarchal social contexts to liberate themselves from structural domination of men's power. This is the within self-power generated by the needs of living. Within selfpower of women facilitates them to cross the border of the boundary of women to be caged at homes created by gender stereotypes in patriarchal contexts. The power within self helps them to resist the male domination and familial restriction or control and hence to foster the freedom and self-determination of women for choosing careerbuilding.

\section{Feminist Power Perspective: Gender Oppression and Resistance}

In particular, in this paper, we have used feminists' ideas of power as gender oppression and resistance to analyse the phenomena of patriarchy faced by three women involved in male-dominated training courses and jobs. The ideas of gender oppression enabled us to look at structural domination of power held by men, thereby creating sexual division of labour. The structural division of labour has an attempt of placing women at the margin of social and economic roles. The feminist power perspective helped us to explain the gender roles defined structurally for not making access to women in TVET activities. In so doing, we have described "the women's 
situation as the consequence of a direct power relationship between men and women in which men had fundamental and concrete interests in controlling, using, and oppressing women" (Lengermann \& Niebrugge, 2011, p. 470). We looked at how and why the women were in subordinated positions and how they were resisting the subjugation of their interest in being professionals in the TVET sector. In so doing, mainly, we have used the perspectives of radical feminism as the ideas of gender oppression and women's resistance for unleashing themselves with their own inherent power of agency and empowerment.

We were in the line of how women were structurally denied equal opportunities in their own social contexts, particularly in participating in TVET programmes. In addition, we looked at how they were violently oppressed by the systems of patriarchy (Monrow, 2007). We intended to visualise the gender stratification created by patriarchy has put them under domination and subordination. Moreover, this was a fundamental structure of society which coerced them to be unequal being. Historically rooted notion and accordingly endured social structure, men as superior and women as inferior, compelled them to be in the lowered social and economic status (Rege, 2003). Thus, the perspective has facilitated us to see the unequal distribution of power between men and women creating hierarchies, thereby requiring women to struggle or resist for accessing education, particularly the TVET programmes. Further, the ideas helped us to analyse the gender-based violence such as sexual abuses (Wallace, 2006) faced by the research participants.

On the other hand, with the support of the perspectives on gender oppression, we analysed the resistance power of women on patriarchal domination. The women resist the power in patriarchy through their consciousness so that they can recognise their own values and strengths (Whitehead, 2007). The empowerment of women that support them to reject the patriarchal pressures to see themselves as weaker, dependent, and second class. With this inherent power of women, there exists "a critical confrontation with any facet of patriarchal domination whenever it is encountered" (Lengermann \& Niebrugge, 2011, p. 474). Moreover, we discussed how the willingness and knowledgeability of women as agency served as forces of resisting socially and culturally constructed and rooted gender stereotypes that placed them in the suppressed position. 


\section{Methodology: Case Study}

We used a qualitative case study to understand the phenomena of gender stereotypes in TVET through the use of multiple sources of information (Yin, 2003). This method enabled us to examine the data within a specific context closely. We selected three women as individual cases who had experiences of engaging in training courses of male-dominated occupations. The case study facilitated us to investigate contemporary real-life phenomenon through detailed contextual analysis of participants (Zainal, 2007). It was appropriate to see the issues through a variety of lenses that allowed for exploring multiple facets of the phenomena to be revealed and understood. This was because we intended to understand the perspective of women who were graduated in male-dominated vocational training and engaged in their works. We selected the participants purposively from three different vocational occupations such as mechanical trade, masonry, and Information Technology.

In line with Yin (2003), we used multiple sources of information (evidence) and multiple data collection methods intending to get rich data. We acquired knowledge in a variety of ways, through in-depth interviews and observations. We interviewed the participants with sufficient probing, which allowed us to understand their experiences of vocational training and jobs in which they engaged. In-depth interviews were more flexible, which allowed the participants to change the course of the conversation and bring up new issues that we had no preconceived (Axinn \& Pearce, 2006). We believed that the knowledge was there in what they expressed. But, again, we thought that a lot of knowledge existed in other forms that are non-discursive and hence we used informal observation for collecting information. We maintained notes and journals in the field (Brown, 2011).

The data analysis and interpretation began from the development of transcription of interview data. We read and re-read the transcribed data as a preliminary analysis to identify major ideas or themes. We then used data analysis as a process of bringing order and interpretation textual information (Marshall \& Rossman, 2014). In other words, data analysis involved the process of organising what had been seen, heard and read so that we could make sense of what had been learned. On the ground of data, we attached meaning and visualised from theoretical perspectives. 
Women in TVET | 21

\section{Struggle Against Gender Stereotypes}

Surakshya, from Baglung district, West of Nepal, was the third child of a middlelow class family. She was active and good in study. She wanted to join vocational education after completion of her School Leaving Certificate (SLC) from a public school of Baglung. She requested to her parents about admission, but they did not agree upon her request. She said, "I wanted to join intermediate in Science and Agriculture after SLC, but my parents did not agree to join me as it was not affordable for them." She added, "All the boys in my family are continuing their education after SLC, and two sisters dropped out after SLC as they got married early." She had no interest in general education (formal school education that has been designed to develop students' general knowledge, skills, and competencies and to prepare them for more advances in educational programmes). She time and again appealed to her parents to admit her in the mechanical trade. She found that the course she wanted to join was cheaper in Himalaya School of Engineering and Technology (HSET).

Surakshya was encouraged by her brother to join this course as he had graduated in a mechanical diploma from HSET. Her brother tried to convince the parents by saying that this course would open the door to many opportunities in employment. Her mother rejected to send her away from home to further study, saying that girls were not supposed to go out from their home. It was difficult for her to convince her father as the father thought that the course was not for girls, but was only for boys. Her mother believed that it was difficult for girls to use mechanical tools and equipment. Her parents were socially trained to accept these social values, which created virtues of passivity (Friedan, 2011) for allowing her to go away from home and take part in the assumed works of males. The parents had a belief that women should be under the care of others. The social value was against making her independent professional being. The socially constructed beliefs of her parents were the virtues that were intending to limit the opportunities of education and employment.

Finally, a teacher of Surakshya convinced the parents when he requested to them to send her to study further away from home as he knew Surakshya could do something like an intelligent and strong girl. Her parents agreed to send her to join mechanical trade in Kathmandu, whereas the duration of this course was for 29 months. She was very excited to join the course she wished and was admitted in 2016 in HSET. 


\section{2 |I. M. Rai \& P. Joshi}

Regarding this, she shared, "Conservative thoughts and lack of education are the main reasons for not sending girls for vocational education." She further added:

Poor parental awareness about the importance of TVET also plays a vital role for less participation of girls in such a vocational course. Parents also think that it is the matter of prestige having their son educated in society. They seem to be more serious about the son's education than daughters.

We understood that the gender stereotypes of not to educate girls and send away from home compelled to happen discrimination in case of Surakshya. Because of the social norms and values, her parents discriminated between son and daughter. There was established social values of confining her to the narrow walls of home neglecting education and career aspiration (Friedan, 2011). However, Surakshya was quite happy, as she had completed her mechanical trade course. She joined this course, thinking that she would get better opportunities and helped her family to run easily with a better income. In so doing, she tried to get a job. She found it somehow difficult to get it because the employers did not believe her that she could efficiently and effectively perform the assigned tasks. According to her, the employers thought that the job was designed for male-only.

Surakshya felt that the people assumed that the women could not participate actively and perform competently in mechanical trades. She experienced that the people were less interested in recruiting women in the mechanical trade. She shared, "People think that women are not capable of doing all the things that men can do." The employers thought that men could perform better than women from all perspectives as the men were considered physically and mentally stronger than women. We understood that it was due to patriarchy Surakshya was thought to be inferior. She was under suppressed position due to the social construction of gender, which limited her to access in maledominated jobs in the society. There was no equal opportunity in education as per the individual capacity; rather, it has been derived by gender (Ritzer, 2000). Patriarchy as an ideology and social system propagated male supremacy or male power and superiority over women as natural and God-given. A patriarchal ideology was the key factor in gender inequality in the context of Surakshya. However, she had confidence in engaging in mechanical works like that of male. 
Women in TVET | 23

\section{Response to Lack of Freedom for Career Choice}

Urina, aged 26, grew in a family of rural area of Kavre. She joined her school when she was five years old. She felt that she was loved by her parents much. She found that it was difficult for her to go to private school as it was very far from her house. Her parents did not allow her to go away from home and compelled to study in a community school as it was nearby her house. Her parents worked on the farm. She was supposed to take care of her three years old younger brother. Because of this daily schedule, she had to leave school and could not continue her study. But, when her brother was admitted to a private school, she also went back to her school after the gap of three years. She noted, "I felt very happy because I got a chance to go to school again." She was fully responsible for taking her brother to school and bring him back home every day. So, she did not get enough time to study even though she appeared her School Leaving Certificate (SLC). She passed her SLC in the second division from the community school.

After SLC, she wanted to join Information Technology (IT) course in a Polytechnic Institute (PI), but her parents suggested to study nursing course which they said acceptable and prestigious in the community. But, she joined an IT course when her parents agreed with the condition of going to college from home instead of staying at the hostel. She said, "My parents were worried about the badmouthing of community people, and they were the victim of conservative thoughts. They think that it is very difficult for girls to stay away from home to study." When she was sharing her experiences, we found that she was very committed to fulfilling her goal of studying IT course. She shared,

Individual interest and commitment are very important in one's success in life.

Women also can be successful as men if they have the decision to choose their career path after school education. People think that such a technical course cannot be handled and accomplished well by the girls. Most of the girls are compelled to join the course as their parents want.

Urina said that she was very happy with what she achieved in the IT course. She joined and completed IT diploma with high expectation within three years, but she did not find any relevant job in her local community. She had a job chance in an organization out of her community, but her parents did not want to send her out of the 


\section{4 | I. M. Rai \& P. Joshi}

village. It was not possible for her to find a job in the village or near the village as IT was a city-based programme. Her male counterparts who completed the course were all involved in jobs out of the village or in any place of the district where they found. She added, "I think our society does not believe in women's work and involvement of women in such professions." However, she has developed self-confidence as a female professional, demonstrating that a woman has the ability to carry out so-called maledominated jobs. She has not got any official job, but she engaged in private works of people. She was called by the local people who faced difficulties in their communication technologies. She added:

I feel sad when someone harasses me by saying something that is not my profession. Many people do not believe that I can do this work. They think that it is the men's profession. However, there are some positive thinkers in our society. They encourage women to choose such a profession. So, I think society has taken me as a courageous woman. I know our society is male-dominated. I think society does not think positively for women until and unless they succeed in their work. The same case applies to me. In my profession, women's participation is very low, and most of the time, I have to engage with men everywhere. I have to work, walk, and eat with them in public. At times, my colleagues blamed me that Urina always stays with boys.

In the case of Urina, it comes to know that she was restricted to grab the job opportunity outside the village due to the stereotype of imaging woman as a housekeeper. She was confined to work in the village as a freelance consultant to serve the needs of the local people. The parents of Urina who held a belief of sending daughters out of home alone for jobs or any other purposes is harmful. In addition, she experienced the suspect and blaming of colleagues that she engaged in negative relationships with the boys while she worked together with the boys. On the other hand, she experienced that the employers did not believe in women's work. They still think that women do not work full time. Most of the women come late and go home soon for their household work. Patriarchy within the household or in the society did less encouraged her to engage in male-dominated profession meaningfully (Ogunleye, 2009). However, Urina was all the time struggling for structural domination, demonstrating her commitment and confidence. This was her agency against the gender 
stereotypes that her family members and people in the community had. She was continuously resisting the structural power in the patriarchal society (Brantley, 2001).

\section{Resisting Cultural Barriers to Access Education}

Kabita, aged 35, lives in a rural area of Kavre district with her five family members. She always thought about her family and children on how to fulfil their basic needs. After the completion of her school education, she could not join the vocational course as she was sent to her husband's house after her marriage at the age of 16 . Unfortunately, her parents were against her interest in further study, and they compelled her to get married. The married life got into big trouble. In the following year of her marriage, she got a baby girl as her first child. She had multiple responsibilities of being a mother, daughter-in-law, a wife and a homemaker. This situation made it very difficult for her to manage time for her study (that she wanted to join a TEVT course). Her father-in-law and mother-in-law were not in favour of supporting her for further study as they thought that their daughter-in-law was supposed to stay at home and do the entire household work.

When Kabita's neighbour suggested getting training of a three-month masonry which would help her to gain skill in a related occupation, she was interested in being trained and work on it. Despite the disagreement of her mother-in-law, she decided to get masonry-training from the CTEVT. After a successful interview, she joined the training in 2017. When her training started, she found it totally different than her expectation. The training was conducted in a public school scheduled from 6:00 am to till 11:00 am. On the very first day of her training, she went to her theory class, where she found 20 participants. Out of 20 participants, she was the only female participant.

Kabita came late in the training class as she had to accomplish all the household chores. She added, "My family members did not allow me to go for training unless I did not finish all the works and fed them on time." She further said, "It was a very hard time of my life when I look back to my past." But, she shared that it was somehow the terrible moment for her to involve in and complete the training because her colleagues and even sometimes the trainers too teased her for no reasons. "I sensed that the trainers and other participants thought that the training was designed for male-only", she shared with us. The trainers were aware of that though they never stopped discriminating her during the entire training period. 


\section{6 | I. M. Rai \& P. Joshi}

Finally, her determination led her to the successful completion of three-month masonry training, even with those all the obstacles and difficulties that she faced during her training period. She was very happy after being a well-trained masonry, but she felt very sad due to people's reaction to the training that she had recently completed. She had not been officially recruited anywhere; rather, she was working in local construction sites particularly crafting of building and fabricating in stone, brick, or concrete block and sometimes plastering the walls. She has been earning more money than before. When we personally asked her about vocational education/ training, she replied,

Vocational education/training is key to success for those who have not completed their formal education from college and universities. It also helps them to increase their income, which helps them to run their house easily. It is very difficult for a female to struggle in such a male-dominated society. I think I could complete this training because I was self-inspired and motivated since my childhood. As a result, now it has become easier to fulfil my living requirements. But, Ifeel that the people have conservative thoughts which have blocked many opportunities for success to the females.

From the Kabita's experiences, we understood that she faced gender-based violence such as child marriage, teasing, and discrimination in her life and even in the process of training. However, she resisted all these and crossed the boundary of traditional stereotypes of restricting women at homes and denying to involve in male-dominated works. The stereotypes were socially constructed laws and rules, causing social discrimination for women with their less representation in male-dominated jobs (Scullen, 2008). However, she had strong motivation and inspiration, which facilitated her to cope with the patriarchal thoughts and practices in society and the learning contexts.

Kabita was under the domination of patriarchy with beliefs that women are unable to perform male-dominated tasks. The structural and cultural values were the barriers for meaningful engagement in learning hindering to guarantee her basic human rights of equal opportunity in education (Bhattarai, 2017). However, as discussed above, we understood that the resistance against the structural barriers she came to the liberation at least working and earning from male-dominated work, masonry. This was because she 
became able to overcome from the discriminatory behaviour at homes and training period. She faced unjustifiable behaviour from others which were predominant in her social context. She was not in the context of beliefs that all human beings have certain essential features, capacities, moral, and self-actualizations (Ritger, 2000). She faced inequality between men and women assigned by gender as social construction having bias in the context of learning and working. However, she had her own inherent power (motivation and commitment) of resisting the gender stereotypes in her living and learning contexts.

\section{Discussion}

Based on the above cases, it became apparent that the three women, involved in the training courses and occupations which were assumed for males, got dominated by the power which was unequally distributed between women and men in the society. The gender-structured families of those women unjustly distributed the burdens of works at homes. The males were powerful and decided to choose the career paths of women. This was the power of resource possessed in males attempted to put them aside in terms of getting opportunities for self-development and economic security. "Gender difference was the velvet glove on the iron fist of domination was defined power" (MacKinnon, 1989, p. 219). Thus, those three women in TVET were facing gender difference due to the domination of power of males. The power that held in men influenced them for deciding to take opportunities for engaging in TVET programmes. Socially and culturally rooted stereotypes of not to allow women to engage in maledominated works outside of the homes or communities were mutable characteristics, dispositions, and practices. The exercise of power held by males in a patriarchal social setting was pervasive that was the basic "fact of male supremacy" which caused "no woman escapes the meaning of being a woman within a gendered social system" (MacKinnon, 1989, pp. 104-05). Moreover, the power held by men manipulated and controlled the access (Frye, 1983) in TVET related jobs which were assumed as males' occupations.

Under conditions of subordination, the three women typically were unable to access the relevant jobs out of their homes and communities. They were denied to exercise their right to self-determination, leaving them to subjugated positions in terms of getting employment. The gender difference was constituted by domination, and "the 


\section{8 | I. M. Rai \& P. Joshi}

patriarchal construction of the difference between masculinity and femininity was the political difference between freedom and subjection" (Pateman, 1988, p. 207). Thus, the three women (as cased above) faced multiple forms of gender-based violence such as child marriage, discrimination, harassment (teasing), socio-economic marginalization, lack of power or autonomy over one's work (Young, 1992, pp. 183193).

On the other hand, however, from the above cases, it is apparent that the three women generated power as a capacity or ability; specifically, the capacity to empower or transform oneself and others through engagement in male-dominated TVET programmes and related jobs. Further, they had self-determination, commitment, confidence, and enthusiasm for coping with the adversities created by the socially constructed gender stereotypes. These were transformative power (Wartenberg, 1990). They resisted the male power as domination generated through their agency such as willingness, the capacity of making a valued career choice, and knowledgeability (Sen, 2000). The motivation, potentiality, and willingness of women in order to engage in TVET programmes helped them to transform self and resist the male supremacy in terms of being autonomous professionals.

This was the agency of the women as the power which helped them to liberate themselves to move ahead in career paths through engagement in the assumed males' works. They developed a level of competency through training, and that was a form of knowledge or skill power which enabled them to explore alternative ways of changing self towards more autonomous being and self-dependent being in the economy. This was the power as "capacity to produce a change" through empowering self and others (Miller, 1992, p. 241). Thus, in the cases above, the women had "power-from-within" by which they made a choice and engaged in the TVET courses and jobs which supported their livelihoods. It was transforming power but not a controlling power. This was "on the side of the power that emerged from within, and that was inherent in them" (Starhawk, 1987, p. 8). The agency as power was a life-affirming and empowering force. This power of women helped them to overcome from male domination, thereby struggling for their self-entitlement and pursuing their own income-generating activities. 
Women in TVET | 29

\section{Concluding Remarks}

The agency of women that is shaped by the living needs of themselves serves as the power to struggle against gender stereotypes of devaluing their ability to engage in assumed education and jobs for males. The women's agency that comes from within the powerlessness in a particularly patriarchal society facilitates them to resist the structural power domination. The two opposing powers, such as socially constructed and rooted gender stereotypes of restricting women in male-dominated works and the inherent power of agency of women grapple in a patriarchal social setting. The interaction of these forces ensures a negotiation, thereby fostering a way to engage in making a life. However, women's right to self-determination in terms of choosing their career paths fosters depending on their way of making negotiation with the power held in patriarchy. Thus, women's agency (motivation, commitment, knowledgeably, and capacity of making a valued choice of a career path) leads them to freedom of choice (Sen, 2000) for making their living easier. The agency as resource power that confronts with the stronger power held by the males and patriarchal social structures and supports to cope with the vulnerability of living.

\section{ORCiD}

Indra Mani Rai (D) https://orcid.org/0000-0002-0848-3735

Pashupati Joshi (D) https://orcid.org/0000-0003-4087-2666

\section{References}

Axinn, W. G., \& Pearce, L. D. (2006). Mixed method data collection strategies. Cambridge University Press.

Bhattarai, S. (2017). Social status of Nepalese single women and perception on remarriage: A case study of Pokhara Lekhnath Metropolitan City. Journal of Development and Social Engineering, 3(1), 49-58.

Budhathoki, N., Dahal, M., Bhusal, S., Ojha, H., Pandey, S., \& Basnet, S. (2012).

Violence against women by their husband and postpartum depression. Journal of Nepal Health Research Council, 10(22), 176-180. https://bit.ly/339VruW Brantley, J. (2001). Women's contribution to sport in the 20th century. Olympic Review, 27(41), 55-60. https://www.cabdirect.org/cabdirect/abstract/20023018740 
Brown, C. (2011). Exploring the concepts of knowledge adoption and conceptual impact: Implications for educational research submissions to the research excellence framework. Education, Knowledge and Economy, 5(3), 137-154.

https://doi.org/10.1080/17496896.2012.673938

Choe, N. (2005). Economic dependence, gender, and the division of labor in the home:

A replication and extension. Journal of Marriage and Family, 62(2), 322-335.

Demissie, M. M. (2017). Evaluating the perceived effectiveness of the leadership styles of deans in Ethiopian governmental technical and vocational education and training (TVET) colleges [Doctoral dissertation, University of South Africa].

http://hdl.handle.net/10500/23607

Duflo, E. (2012). Women empowerment and economic development. Journal of Economic literature, 50(4), 1051-79. https://www.nber.org/papers/w17702

Friedan, S. (2011). Feminism and translation in the 1960s: The reception in the feminine mystique. Translation Studies, 7(3), 267-283.

Frye, M. (1983). The politics of reality: Essays in feminist theory. The Crossing Press.

Gyawali, A. R. (2011). Increasing women access to financial resources through microcredit of Nepal's community forestry. International Journal of Social Forestry, 4(1), 1-16. https://bit.ly/3i7HoKw

Hart, J. (2008). Mobilization among women academics: The interplay between feminism and professionalism. NWSA Journal, 20(1), 184-208.

Helvetas Swiss Inter-cooperation Nepal. (2013). Annual report 2013. https://assets.helvetas.org/downloads/annual_report_2013_1_1.pdf

Lengermann, P. M., \& Niebrugge, G. (2011). Contemporary feminist theory. In G. Ritzer (Ed.), Sociological theory (pp. 454-498). McGraw-Hill.

MacKinnon, C. (1989). Toward a feminist theory of the state. Harvard University Press.

Marshall, C., \& Rossman, G. B. (2014). Designing qualitative research. Sage.

Miller, J. B. (1992). Women and power. In T. Wartenberg (Ed.), Rethinking power (pp. 205-235). SUNY Press.

Monrow, P. T. (2007). Intersubjectivity. In G. Ritzer (Ed.), The Blackwell encyclopedia of sociology (pp. 2400-2402). Blackwell.

Ogunleye, T. (2009). Gender differences in job ability perception and task performance among professionals in male dominated professions. Edo Journal of Counselling, 2(1), 66-74. https://doi.org/10.4314/ejc.v2i1.52655 
Pandey, J.K. (2014). Women empowerment through self-help group: A theoretical perspective. Journal of Culture, Society and Development, 4, 91-94. https://www.iiste.org/Journals/index.php/JCSD/article/view/10038

Pateman, C. (1988). The sexual contract. Stanford University Press.

Rege, S. (2003). Sociology of gender: The challenge of feminist sociological knowledge. Sage.

Ritzer, G. (2000). Sociological theory (5th ed.). McGraw-Hill.

Sen, A. (2000). Development as freedom. Oxford University Press.

Scullen, J. (2008). Women in male dominated trades. It's still a man's world. Saskatchewan Apprenticeship and Trades Certification Commission.

Starhawk, A. (1987). Truth or dare: Encounters with power, authority, and mystery. Harper.

Wallace, C. (2006). An introduction to sociology: Feminist perspectives. Routledge. Wartenberg, T. (1990). The forms of power: From domination to transformation. Temple University Press.

Whitehead, J. C. (2007). Feminist prison activism: An assessment of empowerment.

Feminist Theory, 8(3), 299-312. https://doi.org/10.1177/1464700107082367

Yin, R. K. (2003). Case study research design (3rd ed.). Sage.

Young, I, M. (1992). Five faces of oppression. In T. Wartenberg (Ed.), Rethinking power (pp. 300-326). SUNY Press.

Zainal, Z. (2007). Case study as research method. Universiti Teknologi Malaysia.

\section{To cite this article:}

Rai, I. M., \& Joshi, P. (2020). Women in TVET: Contestation of agency and patriarchal power for liberation. Journal of Education and Research, 10(1), 16-31. https://doi.org/10.3126/jer.v10i1.31895 